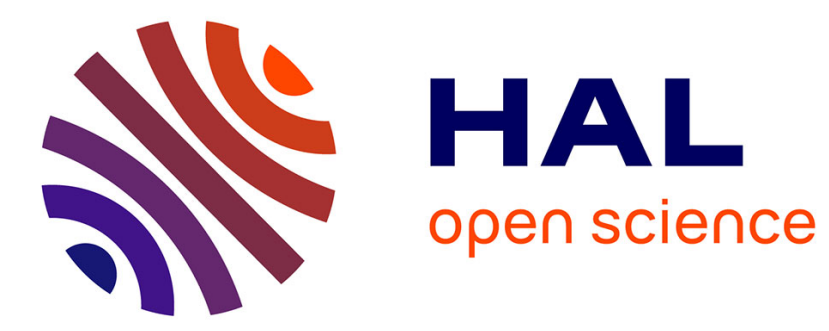

\title{
The Politics of European Public Health Data
}

François Briatte

\section{To cite this version:}

François Briatte. The Politics of European Public Health Data. Scott L. Greer; Paulette Kurzer. European Union Public Health Policy: Regional and Global Trends, Routledge, pp.51-63, 2012, 9780415516648. hal-00793255

\section{HAL Id: hal-00793255 \\ https://hal.science/hal-00793255}

Submitted on 21 Feb 2013

HAL is a multi-disciplinary open access archive for the deposit and dissemination of scientific research documents, whether they are published or not. The documents may come from teaching and research institutions in France or abroad, or from public or private research centers.
L'archive ouverte pluridisciplinaire HAL, est destinée au dépôt et à la diffusion de documents scientifiques de niveau recherche, publiés ou non, émanant des établissements d'enseignement et de recherche français ou étrangers, des laboratoires publics ou privés.

\section{다(1)(2)}

Distributed under a Creative Commons Attribution - ShareAlikel 4.0 International 


\title{
The Politics of European Public Health Data
}

\author{
François Briatte \\ University of Grenoble
}

\section{Introduction}

This chapter examines the effect of public health data on European policymaking. Political stakeholders of all kinds and at all levels of government are frequently observed making non-trivial use of public health data, often in the form of indicators such as mortality rates or expenditure levels. ${ }^{1}$ Virtually all forms of strategic reasoning and communicative action are infused with such indicators, most of which have become increasingly available to decision-makers through national and supranational administrative units, academic research centers and third parties like think tanks or international organizations. Nothing about public health data might therefore be deemed entirely new, but their widespread diffusion within and across borders suggests that their political effects may increase.

Given the essential role of the European Union (EU) as a venue for crossnational policy learning, it is then necessary to ask how public health data translate into public health politics when European-wide indicators are used as benchmarks of policy success-or failure. The political valence of public health data cannot be discounted as merely anecdotal insofar as death rates or percentage points of gross domestic product are easily transmogrified into sources of fame or shame for the governments that account for them. Specifically in the context of public health, where numbers frequently stand for either sick or dying populations, the symbolic weight of aggregate measures such as prevalence or survival rates can carry the same psychological impact that pain and death induce at the level of individuals (Jennings 1999). In that respect, there is nothing trivial about a mortality table, however anonymous its individual observations.

Over the past decade or so, systematic indicators have been developed by EUlevel working groups to 'monitor' Member States, a terminology reminiscent of the work done by other supranational organizations like the (OECD) or the World Health Organization (WHO). The principles that underlie this practice, which can be routinely observed in bureaucratic environments, are deeply political: not only do data empower its agents with 'hard facts' and 'objective evidence', they also open up the possibility of measuring macro-level performance in the form of cross-sectional rankings or time-varying indicators. These, in turn, can be used as argumentative weaponry in discussions over the state of public health in individual Member States or at the abstract level of the European region. The myriad symbolic tokens that are mobilized in the process of data reporting, such as in the calculation of an 'average level' of mortality in European countries, are then turned into powerful cognitive cues in the speeches and writings of bureaucrats, politicians and interest groups alike. 
This chapter specifically aims to describe the transformative effects of EU-level public health data on health policy-making. At the more general level, it also aims to show how a more precise understanding of the processes at play in public health data, namely quantification and standardization, might feed into current understandings of Europeanization. 'Europeanization' is still what semiotics refers to as a floating signifier, that is, a notion that does not point to any agreed upon meaning. ${ }^{2}$ Yet, in its most fundamental incantation, Europeanization does entail the idea of a collective space of reference that is shared by individual Member States, and within which interactions are perceived to produce significant effects at the European and the domestic levels. Public health data directly contribute to materialize this space of reference when such things as 'Europe-wide data' or even 'European data' start making sense to academics and to their human subjects of inquiry. In that sense, and several others, the matter of understanding how public health data has become a topic of interest for European political actors is closely linked to the scientific challenge of analyzing the Europeanization of public health policy in both practical as well as theoretical terms.

The empirical research question that sustains this inquiry has to do with how European institutions think, or rather, how participants in the EU policy process make sense of what they advocate, claim and discuss among each other. The puzzle takes particular importance for us at the level of the European Commission, because the object under examination, public health data, is produced and/or analyzed in part by Commission services. Specifically, the health statistics around which much of the analysis will revolve are often borne out of joint ventures of the Directorate-General Eurostat (DG Eurostat) and Directorate-General for Health and Consumers (DG Sanco), the departments respectively responsible for statistics and for health issues within the administrative bodies of the Commission. The Directorate-General for Research and Innovation (DG Research) has also provided funding for a lot of the public health data that eventually gets spread through the EU statistical apparatus and well beyond it. Given the source of the data for this analysis, it likely expresses a strong 'Commission bias' that understates and fails to document appropriately the diffusion and discussion of public health data in other EU institutions. Nonetheless, parliamentary debates or Council meetings do show that public health data is actively mobilized in these venues as well. ${ }^{3}$

Finally, the theoretical framework used in the present inquiry draws on what has been termed 'common knowledge' in a different political setting (Culpepper 2008). Schematically, the notion of common knowledge designates an intersubjective configuration of human cognition where actors are mutually confronted to "a social fact that cannot be individually wished away" (Wendt 1999: 161, cited in Culpepper 2008: 4). The essential property of common knowledge lies in the impossibility for political actors to discard its informational content. Specifically, once this form of knowledge has been shared between them, "its invulnerability to unilateral change" then allows it to produce "an independent impact on the bargaining power of actors" (Culpepper 2008: 4-5). ${ }^{4}$ Common knowledge requires a form of "convergent diagnosis" won through persuasion and "crossover appeal" among political actors (Culpepper 2008: 5-7). As this diagnosis erodes past conceptions and delegitimizes their institutional settings, it coerces actors into experimenting with new mental sets 
under a high degree of cognitive uncertainty. The result of that process is the consolidation of a new ideational model to which political actors are eventually led to adjust their future strategies.

The following sections apply this analytical framework to the production and diffusion of public health data among European policy-makers. Section 2 describes the most salient characteristics of the EU-level consensus that has gradually emerged and partially overridden former visions of public health. Section 3 then turns to EU powers over public health data and how even a constrained mandate over health policy can translate into substantial EU-driven activity in the field of public health. Section 4 concludes on not-so-future challenges for public health policy in Europe.

\section{Technical characteristics of the issue}

\section{European public health data and government by numbers}

Public health data is a compound of systematic observations that aim at measuring the state of health of selected populations. Since the inception of public health policy, these data have frequently taken the form of statistical reports commissioned by political authorities, including the European Commission, which mobilizes its own staff, national representatives from Member States, other international organizations and private interests. ${ }^{5}$ With regards to public health, the Commission has established particularly tight collaborative links with the WHO Regional Office of Europe, which works with European as well as Central Asian countries.

The keywords of the aforementioned institutions frequently refer to the lexical universe of quantification: in each of them, "data and evidence"-or simply "databases"-support the development of cross-country reports, geographical atlases and other communication tools such as Web platforms to explore tables and graphs built out of international health data. Some of the most detailed data series echo the origins of statistical integration in nation-states and focus on mortality and causes of death, using the successive versions of the International Classification of Diseases (ICD) as well as age-standardized death rates tailored specifically for European demographics. ${ }^{6}$

The history of modern state formation in Western countries indicates that the quantification of a territory is a precious power resource that political authorities have struggled to extract from the populations they rule over, in order to turn collective and discrete social entities into administrable labor or warfare power (Foucault 2004). By analogy, European politics is often conceptualized in the form of a conflict-ridden relationship between the supranational authority of EU institutions and the domestic preferences for national sovereignty of national governments accountable to their populations. The precise amount of statistical knowledge that the European Union has secured over nation-state territories is then not just an analogy: it measures the degree of precision with which the EU scrutinizes its Member States. ${ }^{7}$ That enterprise of turning populations into legible entities is in itself a practice intrinsic to modern statecraft (Scott 1998). 
These general observations resonate significantly in public health, which has virtually always belonged to the core mandate of state power. When urbanization made it a pressing concern to maintain the health of the workforce, 'vital' statistics rose to feature prominently along census data in the history of state-driven quantification (Desrosières 2008, 2010). The political history of disease control, however, features frequent acts of resistance to state surveillance, as in the decades since the AIDS epidemic and the emergence of claims to "democratic privacy" (Fairchild, Bayer and Colgrove 2007). As EU institutions successfully invest in the assemblage of public health data at their own territorial level, some of these conflicts are bound to gain a European dimension, gradually shifting the political space of public health towards supranational venues of decision-making. ${ }^{8}$ This new configuration is likely to change the rules of the game for Member States when the legitimacy of a 'European level' for the government of and by numbers becomes virtually unchallenged.

\section{Evidence-based medicine and policy}

The other language that European public health policy speaks rather fluently is the language of evidence-based policy-making, although the arcane language of European bureaucracy sounds very modestly engaged on that path as compared to the 'what works' lyricism of national bureaucracies in regulatory states. ${ }^{9}$ At present, a striking aspect of the nexus of interests that binds medicine to politics concerns the shared legitimacy of evidence-based decision-making in clinical as well as in policy circles, as seen in the wealth of literature on the topic that has blossomed in the past two decades.

Evidence-based medicine designates the scientific practice that aims at "generat[ing] objective knowledge of effective interventions based, where possible, on the results of unbiased experiments" (Daly 2005: 1; Timmermans and Kolker 2004). In the mid-nineteenth century, Edwin Chadwick, a pioneer of public health policy, formulated the oldest definition that one might accept for evidence-based policy, though today the randomization component central to "high-quality" clinical trials is still not applicable to policy-making (Klein 2003). Despite this difference, data-driven practices characterize high modernism and professional competition within both clinical medicine and public affairs. In these areas, establishing an evidence base has been simultaneously controversial and appealing to policy-makers (Harrison, Moran and Wood 2002). ${ }^{10}$

Regulatory reforms in European states are not limited to injecting evidencebased instructions into the machinery of government: other processes such as standardization play an increasing role in defining actual state capacity (Borraz 2007). Similarly, the various tokens of New Public Management have become deeply embedded into the principles of public service reform, inducing an epistemic shift for political and bureaucratic elites towards quantifiable policy performance measured by benchmarks, rankings, indicators of cost efficiency and other forms of public delivery targets (Bruno et al. 2006; Bruno 2008; Ogien 2010). The use of measurement, 
whether passive or active, has affected virtually all European health care systems in the past two decades, in a more or less gradual fashion and with mitigated success. ${ }^{11}$

The overarching logic couched in the deployment of quantification processes and evidence-based discourse at the EU-level is, in the end, fundamentally dependent upon its most immediate clientele, namely, the audience of public and private actors involved in reorganizing health care and public health in the shadow of European governance. To that audience, the investment of European resources into assembling 'EU-level' public health data under the banner of informing policy by evidence has probably looked, and rightly so, like the first step toward a future of shared governance over public health issues. The current state of EU powers and initiatives further confirms that policy-makers have adjusted their behavior to the existence of a political space of European public health, where data is carried by a diversity of stakeholders as a strategic symbolic resource.

\section{EU powers and initiatives}

\section{Public health data and the "chaordic" dynamics of EU health policy}

Having considered some of the cognitive properties of public health data, we turn to its institutional and political foundations, starting with the apparent paradox that EU powers over health matters are prima facie residual. At its origins, the European Union considered the possibility of supranational health authority through a 'European Health Community' but briskly discarded that alternative, as it also discarded several other policy initiatives that tried to pool national resources under a European heading (Guigner 2008a). Concordantly, the EU treaty base has always explicitly rejected the possibility that health care would fall under the remit of European rule-setters, as illustrated today in the unambiguous wording of Article 168 TFEU. ${ }^{12}$ The political legacy and legal framework of European health policy-making hence seems oriented against the principle of European intervention.

However, a model of policy-making that pays attention to spillover dynamics effectively shows that, during the past two decades, policy arbitrages over health care have become increasingly Europeanized through both political and social learning, as shown by the contingencies of European court rulings (Greer 2006), the adaptation of Member States to European directives in the health care sector (Greer 2009a), and the parallel formation of advocacy coalitions and interest groups around health issues in the Brussels beltway (Greer 2009b). Additionally, strategic interactions between the European Commission and the WHO Regional Office of Europe have led EU institutions to strike a series of ideational bargains over multilateral issues such as pharmaceutical market expansion or tobacco control (Guigner 2008b). The overall public health policy arena has thus become increasingly Europeanized, through 'vertically' binding regulatory measures and through 'horizontally' diffused incentive measures (Guigner 2011a).

For more than thirty years, European public health policy has also been shaped by exogenous shocks that have opened policy windows for public health advocates to extend European powers to new areas of public health concern (McKee, 
Hervey and Gillmore 2010). The cumulative sum of EU responses to issues like nuclear radiation, food safety or organ donation has spun into a perhaps 'spineless and toothless' but still identifiable European public health system, currently headed by DG Sanco and populated by three regulatory agencies, a federally inspired health surveillance unit, ${ }^{13}$ and an executive branch responsible for EU programs in health promotion, consumer protection and food safety. ${ }^{14}$ This trend has been progressively matched by explicit mandate adjustments in the EU treaty base, which today prominently asks for the European 'mainstreaming' of health protection at Article 9 TFUE. ${ }^{15}$

While this state of affairs is explained largely by accidental logics and often unwarranted spillover effects, the expansion of public health data collection also contributes purposively to structuring the politics of European public health. EU cross-national comparative data provides a salient and shared argumentative resource on which to sustain policy initiatives and build evaluative judgments about the performance of domestic health systems. Steps taken by EU institutions that engage data reinforce the path of European integration of public health policy. This interplay of institutional and ideational factors has been insightfully coined the "chaordic" dynamics of European integration in health policy. On the one hand, the European health policy field has been formed through unpredictable spillovers and shocks. On the other hand, the accretion of deliberate European strategies aimed at governing over health issues form an "issue-specific, fragmented, and incremental process, necessarily technocratic and patchy, but quite consistent” (Lamping and Steffen 2009, 1375, emphasis removed).

The possibility for EU actors to be more involved - and more influential—in health policy relies on successful statistical integration, which requires organizational development and widespread trust in the reliability of the data. The history of EU statistical integration shows that producing reliable statistics that are available to market agents, policy-makers and the general public has so far been a largely successful initiative for the European Commission and specifically its 'Eurostat' directorate-general (Sverdrup 2006). ${ }^{16} \mathrm{EU}$ statistical services can furthermore count on the cognitive and institutional support of other members in the epistemic community of transnational data purveyors, such as the OECD or the World Bank, which also actively develop standardized health indicators and many other cognitive assets for global governance (Davis et al. 2011). Over the years, the EU has produced several collections of such indicators against which health system performance assessments can be elaborated in domestic policy environments.

\section{The measurement of EU health system performance}

Health performance indicators have been adopted rapidly by international organizations like the WHO, which ratified the principle and then published performance targets in its Health for All strategy in the early 1980s. ${ }^{17}$ The recent history of EU public health, however, tends to show that EU decision-makers expressed more measured ambitions in that regard. Calls to monitor domestic health systems at the EU-level appeared regularly in decisions from the European Parliament and the Council since at least the Community Action Programme on Health 
Monitoring of 1997, though they were implemented within narrower bounds than those recommended by the Commission. In reference to the first EU public health program, published in 2002, ${ }^{18}$ Hervey and Vanhercke (2010: 89) note that limitations were applied to the instrumentation of EU public health data into what would have otherwise read like the formation of a supranational framework of comparative health system performance assessment:

the Commission's proposals 'to stimulate EU-level action on comparing and assessing health care systems' through the program were removed during the first reading in the co-decision procedure in 2001, highlighting great reluctance by the Member States to accept interference in this domain, even if it 'merely' implied comparisons of performance.

Similarly, when another pledge to monitor public health progress in Member States came out of Parliament and Council in 2007, ${ }^{19}$ several Member States requested that the budget of the proposed program be axed to thwart any significant advance in that direction (Baggott 2011: 96). Soft law instruments that encourage cross-national comparison within Member States in order to identify "best practices" for policymaking, like the Open Method of Coordination (OMC), have also had to tread very carefully over health care, partly due to data limitations but primarily because some Member States have expressed their outright hostility to specifically supranational target-setting and performance indicators for health services (Greer and Vanhercke 2010: 209-212). ${ }^{20}$ Even in the case of a policy instrument like Structural Funds, which can be allocated under a 'what works' performance objective, the possibility of running comparative assessment that would concern "the running of the healthcare system" has been prudently ruled out so far (Hervey and Vanhercke 2010: 91).

In 2008, the ratification of the Lisbon Treaty provided another opportunity to further the case of EU-level public health monitoring. The Commission indicated in its draft that it would seek to support, 'initiatives aiming at the establishment of guidelines and indicators, the organization of exchange of best practice, and the preparation of the necessary elements for periodic monitoring and evaluation. ${ }^{21}$ This text now appears verbatim in Article 168-1 TFEU. In a similar fashion, and in line with successive EU and WHO commitments to tackle health inequalities in European countries, an elaborate list of health determinants has now been published under the form of European Community Health Indicators (ECHI), ranging from infant mortality to waiting times for elective surgery. ${ }^{22}$ It seems, then, that the defusing of EU-level health system comparison by understandably concerned domestic political elites has come to existence through the parallel policy pathway of EU public health programmes.

EU health system performance monitoring still bears the marks of opposition from several Member States. Its current state of development is that of an advanced battery of precise and systematic indicators that closely mirror national initiatives in that domain. At the same time, many national governments have invested in prioritysetting through targets in the past decade. In mapping out the strengths and weaknesses of public health in Europe, the EU has found close allies in other international organizations, as well as in more discrete, but nevertheless active and 
vocal, members of its epistemic community, such as the European Public Health Alliance and countless collectives of transnational medical elites. As of today, the joint work of EU services are not only inside rather than outside of the political space of European public health, as underlined in the previous section. They have also built a robust frameset of quantitative measurements that bring together various forms of accountability indicators, ranging from expenditure levels to health system inputs and outputs.

\section{Cancer survival rankings and EU health policy}

Cancer control provides an interesting illustration of the logic outlined so far. Using this example helps understand how the emergence of performance measures can affect future policy-making, but also reveals the still largely accidental ways in which the politics of European public health data unfold over time. The history of EU activity in cancer control indeed predates and surpasses its involvement with the tackling of other diseases, as cancer, along with AIDS and drug use, has been a privileged target of EU programs and regulations. Since the inception of the "Europe Against Cancer" program (Trubek, Nance and Hervey 2008) in the aftermath of the Chernobyl nuclear accident of 1986, several other EU policies have affected all aspects of cancer control, including clinical trials, screening recommendations, biomedical funding, and most visibly tobacco control, where comparative public health data has played an interesting role in the identification of well-disciplined and less-disciplined Member States (Guigner 2011b).

One aspect of cancer control involves measuring cancer survival. Domestic governments are confronted with geographical inequalities in cancer epidemiology that make them aware of regional leaders and laggards within their territory. However, cross-national comparative data in cancer survival rates is a more recent element of common knowledge, which has been crafted by a small epistemic community of European epidemiologists over the past two decades. The EUROCARE research project, which received EU funding from the BIOMED and FP4 programmes, was at the origin of cross-national cancer survival rankings that played an important role in shaping British health policy in the years 1999-2001; at the outset of its reform episode, the British decision created a policy point of reference for the "European average" of health expenditure, therefore injecting European criteria into national health care reform (Briatte 2010).

There is now a significant amount of consensus in reference to EU levels of conformity, in the form of either passive or active promotion of EU average measurements. These express the same logic of appropriateness and conformance as the "average American" did when surveys began having an impact on models of the mass public in the United States (Igo 2007). The political substance of European average levels also intermeshed domestic and supranational interests through the passive uploading of measurements and indicators, leading to a situation where they express crossover appeal to all actors. From 2001 onwards, as McHale (2010: 291) recalls, EU discourse started to act as a bandwagon on health issues as domestic interests had previously defined them, largely through the derivation of institutional health system characteristics: 
... the European Committee of Social Rights expressed concern that there were increased waiting list times in the United Kingdom and they stated that, in light of the data, they considered that 'the organization of health care in the United Kingdom is manifestly not adapted to ensure the right to health for everyone.'

The referential and disciplinary properties of European public health data are only one instance of their political character. This section only scratches the surface of EU initiatives that revolve around public health data: other EU-level projects exist addressing biobanks of genetic information and tissue, as well as clinical trials. Some cross-national initiatives have also been suggested for the regulation of pharmaceutical markets, where domestic interests limit efforts at regulatory harmonization and comparative effectiveness assessments (Hancher 2010: 681). These initiatives follow a different but perhaps more predictable pattern of EU-level interests, strongly associated with market harmonization principles and standardization strategies. ${ }^{23}$ They also operate jointly to mass information programs that advertise, for instance, patient information on public-private partnerships, as well as many other programs that assume a highly educated population capable of (responsible for) making its own health-promoting choices.

Overall, these policy developments have brought market concerns to intermesh with health safety and public health concerns. They have affected the mental models and interest structures of states, markets and societies, reminiscent of what Michel Foucault tentatively captured in his theorization of biopolitics. ${ }^{24}$ The politics of European public health data, which eventually revolve around the definition of health system performance issues across European states, match this general characterization, which carries its own risks, as currently reflected under radical austerity and financial crisis.

\section{Future issues}

In this analysis, the origins and politics of European public health data can be explained by the success of cross-national public health data becoming common knowledge that is shared by virtually all policy stakeholders in the emergent field of European public health policy. The cognitive properties of EU public health data have been gradually matched by institutional opportunities at the EU level, and finally by a structure of interests where Member States tacitly compete to demonstrate high levels of comparative health performance. Every reference to EU benchmarks-such as the 'European average' value of a given health indicator-adds to the cognitive harmonization and statistical 'creep' of European public health data, leading in some cases to significant reform initiatives by domestic political elites in Member States.

While every policy decision may produce positive feedback effects from which emerge path dependence and institutional "stickiness," it is possible that a macroeconomic decision, for instance, to some extent 'reverses' or even 'cancels out' practical policy effects. In contrast, public health policy and the statistical integration of European public health data are hardly concerned by radical reversals that would 
lower the policy sustainability of the public health field. ${ }^{25}$ Harsher privacy rights, for instance, might thwart but very rarely decrease the precision of disease surveillance. Furthermore, the hypothetical policy decision to axe a public health agency like the European Centre for Disease Control would require many efforts not to look like a completely irresponsible move from a public relations perspective, given the critical context in which such agencies have often emerged in the first place. Finally, as research programs and quantitative information progress incrementally, their cumulative sum clearly pushes public health data towards more legibility rather than less, with ever-larger amounts of information becoming available through increasingly sophisticated instruments.

The future of public health is likely a trend toward more integration in the form of data streams under favorable political and technological circumstances. The internationalization of scientific activity is probably also a major contributor in assuring that public health practitioners look forward to a more collaborative epistemic culture. The future of public health looks quite similar to its past, which has also been a history of gradual expansion if one considers the longue durée of public health data. Additional innovations in computer and network infrastructures as well as in statistical and data science, helped by recent initiatives in favor of democratizing access to "open data", are likely to push that trend forward.

There is a bleak side to this rather optimistic narrative. Permanent fiscal austerity, now topped by financial crisis and dubious democratic politics in several European countries, both inside and outside the European Union, are important causes for concern to anyone with a professional interest in health. The universalization of health systems is a reversible trend: it might progress spectacularly somewhere and gradually retrench on a different subcontinent. European countries are not at all immune of the health effects of austerity on welfare, as Stuckler et al. (2009) have shown using the most recent Eurostat data. A country like Greece, which is currently among the most stricken, is at serious risk of bearing higher death rates under radical austerity, whether due to suicide, drug use or lack of access to medical facilities as affordability collapses for large fractions of the population (Kentikelenis et al. 2011).

A cruel irony, of course, might be that the same institutions that are actively supporting these austerity shocks are also providing scientists with the means to analyze their effects on the health of societies. As McKee and Stuckler (2011:2-3) recently put it in their correspondence to the European Journal of Public Health: "As researchers, the least we can do is to document the human costs of the crisis, to tell the stories of ordinary people throughout Europe whose lives are being blighted by radical austerity and risky bank maneuvers. There will be more unintended consequences, albeit difficult to predict, calling for a close monitoring of the situation. Our initial studies, recently published in the Lancet, were very simple to do and cost only our time as researchers." However close the "monitoring", though, the body politic is the locus where the political economy of life and death unfolds (Foucault 2004). Modern states are hardly the sole site of these biopolitics anymore. The macroeconomic agenda of the European Union is, in itself, a public health policy that might enhance or forestall future public health efforts. The data will tell us. 


\section{References}

Baggott, R. (2011) Public Health Policy \& Politics, 2nd ed., Basingstoke: Palgrave Macmillan.

Bossy, T. and Briatte, F. (2011) 'Les formes contemporaines de la biopolitique', Revue internationale de politique comparée 18(4): 7-12.

Borraz, O. (2007) 'Governing standards: The rise of standardization processes in France and in the EU', Governance 20(1): 57-84.

Branch, J. (2011) 'Mapping the sovereign state: Technology, authority, and systemic change', International Organization 65(1): 1-36.

Briatte, F. (2010) The Europeanization of Health System Performance. The EUROCARE study and Cancer Control in England, paper presented at the Seventeenth International Conference of the Council for European Studies (CES), Montreal: Canada, April 15-7.

Bruno, I., Jacquot, S., and Mandin, L. (2006) 'Europeanization through its instrumentation: Benchmarking, mainstreaming and the Open Method of CoOrdination... Toolbox or Pandora's Box?' Journal of European Public Policy 13(4): 519-536.

Bruno, I. (2008) 'Y a-t-il un pilote dans l'Union ? Tableaux de bord, indicateurs, cibles chiffrées : les balises de la décision', Politix 82: 95-117.

Culpepper, P.D. (2008) 'The Politics of common knowledge: Ideas and institutional change in wage bargaining', International Organization 62(1): 1-33.

Daly, J. (2005) Evidence Based Medicine and the Search for a Science of Clinical Care, Berkeley: University of California Press.

Davis, K., Kingsbury, B. and Merry, S. (2011) 'Indicators as a technology of global governance', New York: Institute for International Law and Justice, Working Paper 2010/2 Rev.

Desrosières, A. (2008) Gouverner par les nombres, Paris: Presses des Mines ParisTech.

Desrosières, A. (2010) La politique des grands nombres. Histoire de la raison statistique, $3^{\text {rd }}$ ed., Paris: La Découverte.

Ferrera, M. (2005) The Boundaries of Welfare. European Integration and the New Spatial Politics of Social Protection, Oxford: Oxford University Press.

Harrison, S., Moran, M., and Wood, B. (2002) 'Policy emergence and policy convergence: The case of "scientific-bureaucratic medicine" in the United States and United Kingdom', British Journal of Politics and International Relations 4(1): 1-24.

Faucher-King, F., and Le Galès, P. (2010) The New Labour Experiment. Change and Reform under Blair and Brown, Palo Alto: Stanford University Press.

Foucault, M. (2004) Naissance de la biopolitique. Cours au Collège de France, 19781979, Paris: Seuil.

Igo, S.E. (2007) The Averaged American. Surveys, Citizens, and the Making of a Mass Public, Cambridge, MA: Harvard University Press.

Jennings, M.K. (1999) 'Political Responses to Pain and Loss', American Political Science Review 93(1): 1-13.

Klein, R. (2003) 'Evidence and policy: Interpreting the Delphic oracle', Journal of the Royal Society of Medicine 96(9): 429-431. 
Timmermans, S., and Kolker, E.S. (2004) 'Evidence-Based Medicine and the reconfiguration of medical knowledge', Journal of Health and Social Behavior 45 (Special Issue): 177-193.

Demortain, D. (2008) 'Institutional polymorphism: The designing of the European Food Safety Authority with regard to the European Medicines Agency,' London School of Economics: Centre for Analysis of Risk and Regulation, Discussion Paper 50.

Fairchild, A. L., Bayer, R., and Colgrove, J. (2007) Searching Eyes. Privacy, the State, and Disease Surveillance in America, Berkeley: University of California Press.

Greer, S.L. (2006) 'Uninvited Europeanization: Neofunctionalism, health services and the EU', Journal of European Public Policy 13(1): 134-152.

Greer, S.L. (2009a) The Politics of European Union Health Policies. Making European Health Policy in Germany, France, Spain and the United Kingdom, Maidenhead: Open University Press.

Greer, S.L. (2009b) 'The changing world of European health lobbies', in D. Coen and J. Richardson (eds), Lobbying the European Union. Institutions, Actors, and Issues, Oxford: Oxford University Press, pp. 189-211.

Guigner, S. (2008a) L'institutionnalisation d'un espace européen de la santé. Entre intégration et européanisation, $\mathrm{PhD}$ dissertation, Rennes: Université de Rennes 1.

Guigner, S. (2008b) 'The EU and the health dimension of globalization. Playing the World Health Organization card', in J. Orbie and L. Tortell (eds) The European Union and the Social Dimension of Globalization. How the EU Influences the World, London: Routledge, pp. 131-147.

Guigner, S. (2011a) 'L'influence de l'Union européenne sur les pratiques et politiques de santé publique : européanisation verticale et horizontale', Sciences Sociales et Santé 29(1) : 81-106.

Guigner, S. (2011b) 'L'Union européenne, acteur de la biopolitique contemporaine : les mécanismes d'européanisation normative et cognitive de la lutte contre le tabagisme', Revue internationale de politique comparée 18(4): 78-90.

Hancher, L. (2010) 'The EU pharmaceuticals market: parameters and pathways', in E. Mossialos, G. Permanand, R. Baeten and T.K. Hervey (eds) Health Systems Governance in Europe. The Role of European Union Law and Policy, Cambridge: Cambridge University Press, pp. 635-682.

Hervey, T.K. and Vanhercke, B. (2010) 'Health care and the EU: the law and policy patchwork', in E. Mossialos, G. Permanand, R. Baeten and T.K. Hervey (eds) Health Systems Governance in Europe. The Role of European Union Law and Policy, Cambridge: Cambridge University Press, pp. 84-133.

Humpherson, E. (2010) 'Auditing regulatory reforms', in D. Oliver, T. Prosser and R. Rawlings (eds) The Regulatory State: Constitutional Implications, Oxford: Oxford University Press, pp. 267-282.

Kentikelenis, A., Karanikolos, M., Papanicolas, I., Basu, S., McKee, M., and Stuckler, D. (2011) 'Health effects of financial crisis: omens of a Greek tragedy', Lancet 378: $1457-8$.

Lamping, W. and Steffen, M. (2009) 'European Union and Health Policy: The “Chaordic” Dynamics of Integration', Social Science Quarterly 90(5): 13611379. 
McHale, J. (2010) 'Fundamental rights and health care', in E. Mossialos, G. Permanand, R. Baeten and T.K. Hervey (eds) Health Systems Governance in Europe. The Role of European Union Law and Policy, Cambridge: Cambridge University Press, pp. 282-314.

McKee, D., and Stuckler, D. (2011) 'There is an alternative: public health professionals must not remain silent at a time of financial crisis', European Journal of Public Health 22(1): 2-3.

Márquez, X. (2007) 'Technologies of State: The Technological Foundations of the Modern State'. Unpublished manuscript.

McKee, M., Hervey, T.K., and Gillmore, A. (2010) 'Public health policies', in E. Mossialos, G. Permanand, R. Baeten and T.K. Hervey (eds) Health Systems Governance in Europe. The Role of European Union Law and Policy, Cambridge: Cambridge University Press, pp. 231-281.

McKee, M. and Ryan, J. (2003) 'Monitoring health in Europe: opportunities, challenges and progress', European Journal of Public Health 13 (Supplement 3): 1-4.

Ogien, A. (2010) 'La valeur sociale du chiffre. La quantification de l'action publique entre performance et démocratie', Revue française de socio-économie 5: 19-40.

Patashnik, E.M. (2008) Reforms at Risk. What Happens After Major Policy Changes are Enacted, Princeton: Princeton University Press.

Porter, T.M. (1995) Trust in Numbers : The Pursuit of Objectivity in Science and Public Life, Princeton: Princeton University Press.

Princen, S. (2009) Agenda-Setting in the European Union, Basingstoke: Palgrave Macmillan.

Radaelli, C. and Pasquier, R. (2007) 'Conceptual issues', in P. Graziano and M.P. Vink (eds) Europeanization. New Research Agendas, Basingstoke: Palgrave Macmillan, pp. 35-45.

Risse, T. (2000) “'Let's Argue!": Communicative Action in World Politics', International Organization 54(1): 1-39.

Schmid, A. and Wendt, C. (2010) 'The Changing Role of the State in Healthcare Service Provision', in H. Rothgang, M. Cacace, L. Frisina, S. Grimmeisen, A. Schmid and C. Wendt (eds) The State and Healthcare. Comparing OECD Countries, Basingstoke: Palgrave Macmillan, pp. 53-71.

Scott, J.C. (1998) Seeing like a State. How Certain Schemes to Improve the Human Condition Have Failed, New Haven: Yale University Press.

Sibille, B. (2010) 'Voir l'Europe pour la faire. Un système d'informations géographiques dans la “gouvernance” européenne,' Politique européenne 31: $147-172$.

Sverdrup, U. (2006) Administering Information: Eurostat and Statistical Integration, in M. Egeberg (ed.), Multilevel Union Administration. The Transformation of Executive Politics in Europe, pp. 103-23.

Stuckler D., Basu S., Suhrcke M., Coutts, A. and McKee, M. (2009) 'The public health effect of economic crises and alternative policy responses in Europe: An empirical analysis.' Lancet 374: 315-23.

Wendt, A. (1999). Social Theory of International Politics, New York: Cambridge University Press.

WHO (n.d.) 'History of the Development of the ICD'. Online, available at: http://www.who.int/classifications/icd/en/HistoryOfICD.pdf (accessed 17 February 2012). 
${ }^{1}$ The term 'data' is used hereinafter as an analogue for statistical series made of standardized, quantified measurements, even if a narrative is technically a form of datum. The focus is hence set on numerical rather than literal information.

${ }^{2}$ For a more formal introduction to the conceptual issues that come with the notion of Europeanization, see, inter alia, Radaelli and Pasquier (2007).

${ }^{3}$ Some quantitative studies of health issues in the European Parliament do exist, however; for a fullfledged approach and comparison to environmental issues, see Princen (2009).

${ }^{4}$ This perspective has the intrinsic merit of reconciling the long-established opposition between rationalist and constructionist views, as it grants causal power to 'ideas' deemed appropriate by actors within a scheme of action that otherwise draws on strategic bargaining and consequentialist reasoning from actors who follow their individual 'interests'. The main background assumption of this analytical framework consists in translating the opposition between rationalist and constructionist arguments, initially exposed in the area of international relations (Risse 2000), to the study of European politics. That is arguably not a huge step to take. Common knowledge does indeed seem to be a very suitable candidate for a study of European politics that aims at avoiding the theoretical clash between intergovernmental and constructionist views of the European Union.

${ }^{5}$ There is no reason to believe that this pattern of production is fundamentally different in other families of statistical data, and the observations made here might therefore carry implications for other sectors of European policy-making.

${ }^{6}$ On the origins of population-level quantification by national governments, see Desrosières (2008, 2010) and Porter (1995) for two well-known historical works. The ICD itself has its origins in the efforts of British and French medical statisticians commissioned by international congresses held in Brussels and Vienna (WHO, n.d.).

${ }^{7}$ A different wording closer to the works of Michel Foucault would speak of the EU 'gazing' at its Member States as other dominant groups, like nation states or clinicians, 'gaze' at society. For an elaborate account of the state as an assemblage of such technologies, see Márquez (2007), who draws on Foucault and Weber.

${ }^{8}$ This pattern is neither unique nor universal. For a similar pattern between states, European institutions and geographic information, see Branch (2011) and Sibille (2010); For a different form of spatial politics expressed through the boundaries of welfare, see Ferrera (2005).

${ }^{9}$ On the characteristics of regulatory states in relation to evidence-based policy and other instruments of impact assessment, see Humpherson (2010).

${ }^{10}$ The most illustrative example of that trend probably still lies with the successive Blair and Brown governments (Faucher-King and Le Galès 2010: 42-61).

${ }^{11}$ On the general degree of state involvement in health care system development, management and reform, see Schmid and Wendt (2010) and other chapters in Rothgang et al. (2010).

${ }^{12}$ Specifically, Article 168-1 TFEU specifies that EU action "shall complement national policies", and Article 168-7 TFEU that it should "respect the responsibilities of the Member States for the definition of their health policy and for the organization and delivery of health services and medical care."

${ }^{13}$ On the European Centre for Disease Prevention and Control and its relationship to European health governance, see Greer (2011). 
${ }^{14}$ All measures are documented in the annual reports of the Executive Agency for Health and Consumers (EAHC). European public health programs operate under the conditions of Article 168-5 TFEU, that is, at the exclusion of "any harmonization of the laws and regulations of the Member States".

15 "In defining and implementing its policies and activities, the Union shall take into account requirements linked to the $[\ldots]$ protection of human health."

${ }^{16}$ In addition to the institutional trajectory of Eurostat, other efforts at integrating European public health data have underlined the practical imperfections of comparative data collection and analysis over EU countries (McKee and Ryan 2003).

${ }^{17}$ The WHO Regional Office for Europe published specific European targets in the same years. It should probably be reminded that the WHO has relatively little impact on domestic policies.

${ }^{18}$ Decision 1786/2002/EC of the European Parliament and of the Council of 23 September 2002 adopting a program of Community action in the field of public health (2003-2008).

${ }^{19}$ Decision No 1350/2007/EC of the European Parliament and of the Council of 23 October 2007 establishing a second program of Community action in the field of health (2008-2013).

${ }^{20}$ The relevant policy documentation, such as the Draft Joint Report on Social Protection and Social Inclusion 2010, read like succedanea to the otherwise prolific research on national health accounts and comparative health outcomes developed by the OECD or the World Bank.

${ }^{21}$ Similar objectives can also be found in the white paper Together for Health, published by the Commission in 2007.

${ }^{22} \mathrm{~A}$ shortlist of $88 \mathrm{ECHI}$ indicators was initially conceived by national public health representatives, DG 'Eurostat', DG 'Sanco' (now DG 'Health \& Consumers'), WHO and OECD. For further details, see the ECHI Web pages accessible at http://ec.europa.eu/health/indicators/echi/list/ (last accessed 13 February 2012).

${ }^{23}$ On the mix of public health and market interests that govern over the work of the European Food Safety Agency (EFSA) and the European Medicines Agency (EMA), see Demortain (2008). The third European regulatory public health agency, the Community Plant Variety Office (CPVO), which enforces EU intellectual property rights over genotypes, also fits that pattern.

${ }^{24}$ In a nutshell, biopolitics designate the balance of power established over the lifestyle of populations, in a dual process that both compels governments to rule over the vital signs of their citizenry and confronts individuals to their own responsibility in maintaining a state of health (Bossy and Briatte 2011). While originally studied in West European nation-states, biopolitics is currently understood to have potential empirical applications at all levels of government.

${ }^{25}$ On policy sustainability, see Patashnik (2008). 